\title{
繊維素の角質化及び角質化繊維素の活性化に関する研究
}

\author{
東京工業大学 長 谷部亮・松本健 次 \\ 前田 弘 邦
}

\section{ON THE CORNIFICATION OF CELLULOSE AND THE REACTIVATION OF THE CORNIFIED CELLULOSE}

By Ryo Hasebe, Kenji Matsumoto and Hirokuni Maeda

(Laboratory of Textile Chemistry, Tokyo Institute of Technology, Tokyo)

By measuring the swelling of samples in glacial acetic acid, the cornification of cellulose and the reactivation of the cornified cellulose were investigated, and the results obtained are as follows.

(1) In the dehydrating course of drying, the cornification develops increasingly after the water content has fallen below $50 \%$ in the case of native cellulose or below $80 \%$ in the case of cellulose treated with $10 \% \mathrm{NaOH}$ beforehand.

(2) The cornification is appreciably inhibited by drying after replacing water with organic liquid, and the smaller the surface tension, affinity to hydroxyl group, and the polarity of the liquid, the greater the preventing action of the liquid.

(3) If the cellulose not cornified in drying is placed in the room of moderate humidity, the cornification takes place markedly during storage.

(4) The cornified cellulose is reactivated by treating it with proper liquid; the greater the cohesive energy density of the liquid, the higher the activity as reviving reagent. Acetic acid displays its reviving action only at moderately higher temperature.

(5) Mechanical grinding is exceedingly effective in the reactivation of the cornified cellulose.

(Received 26. 8. 1955)

\section{緒窟}

角質化という現象は緎維素に限らず，一般に無定形

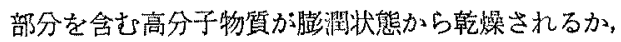

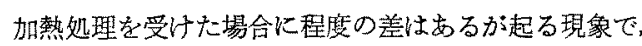
圭の結果姞䯩分子物質の物理的或いは化学的の諸性質 に種々の影響を及ぼす。例えば緎維素の場合，紙や人 造瀻維の機械的諸性質はもとより数昷的に十分解析で

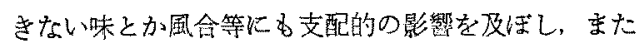
レーョンパルブ,なかんずくエステル用パプの反応

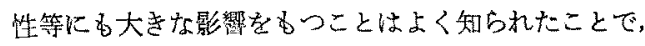
これ等比関する研究は従来極めて多い。

しかして䋐維素の角質化は水で膨洞された状態かっら その水分を除去してゆく，亦なわら脱水乾燥過程に無 定形領域にある遊離の水酸基同志心間に水素結合その 他の結合が起ることによること禹推定に難くないこと である。本報告には篗者等が侻来研究して来たエステ
ル用パルプの反応性に関連して，角質化の起る機構を

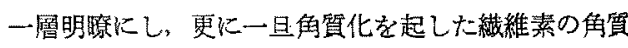
化組䄉の破壊，換言すれば活性化の合理的手段を探求 する目的で実唤を行ったのでその結果の概要を速べる。

\section{実験及び実験結果の考察}

\section{(1) 角質化度の測定法}

まず角質化程度の量的湘定方法であるが，本研究で はエステル用パルプの問題にる関連することから, 常

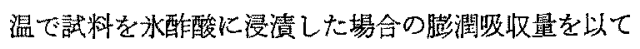
角質化を間接的纪坋較した。けだし，後述する実験結

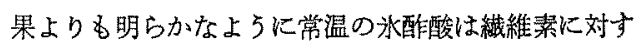
る膨閩力はかなり弱く角躓化組禨を破壊することは殆 んぞないから，瀻維素試料の種々の程度に角質化した 状態をそのままに膨洞吸収量に反映させることができ るるのと考えたからである。角筫化度 (r)としては 次の上うな值を採用した。 


$$
r=\frac{q_{0}-q}{q_{0}}
$$

ここで $q_{0}$ は就繰試料の昜合はこれる水に長時間浸 清した後，またアルカリ処理したるのでは水洗後，数

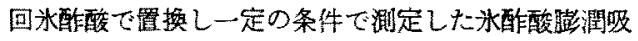
叹量, $q$ は同じく角貿化を起す观理を受けた後の头酢

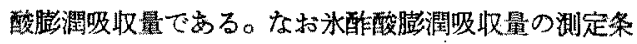
件は次の如くである。水又は他の液体で湿潤した試料 は米醀酸で数回置換洗浄し，絶䩐試料はそのまま $20^{\circ}$ Cの头酶酸中に漫漬し，取り出して過剩の头酿酸を

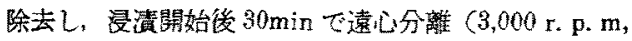

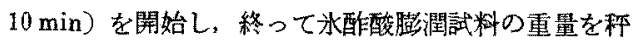
量しこれる洗浄乾煤して試料の䋓乾量を知り両者の

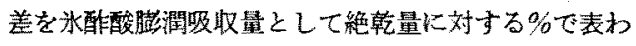
した。

\section{（2）脱水乾燥条件による角斦化の相違}

ます湿閏維素を脱水彰蜗してゆく場合どの程度の 水分含有量加ら顕著な角質化が起り始めるかを夷験乙 た。試料としては便宜上定性滤絓と，これを10\%苛性 ソーダ溶液で常温起理したすのを用いた。これらの試 料をそれぞれ各種水分残留量まで乾燥した後米酿酸で

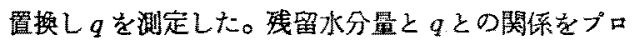
ットするとFig.1に示すようになる。はた残留水分量 と角質化度 $(r)$ の関倸はFig. 2 K示す如くである。10\% 苛栍ソーダ客液て処理した試料の $q_{0}$ は繁処理試料の

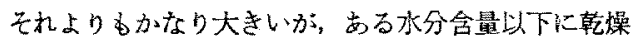
したときのqは殆えど差がない，すなわり $10 \%$ 苛性 ソーダ溶液で処理したののは無処理の6のに比較すれ

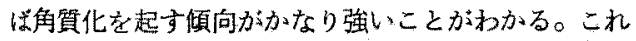

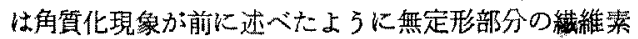

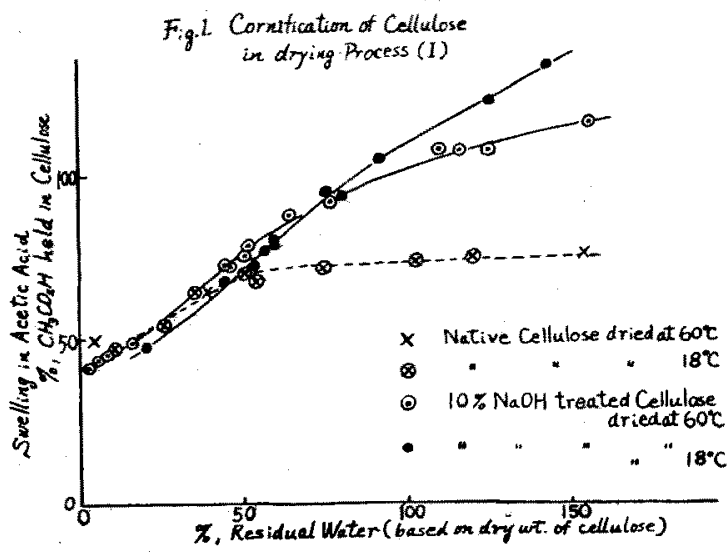

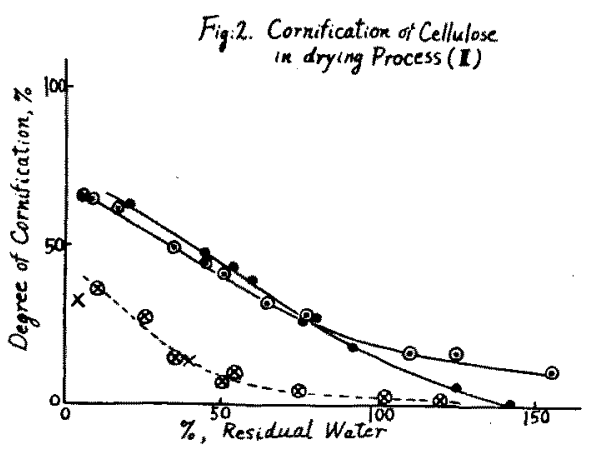

分子に属する水酸基心間に何等かの結合が起ることに

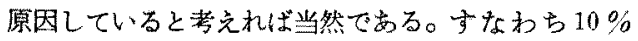
菏性ソーダ洛液起理により無定形部分の多量になった

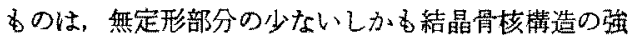
固な無処理のすのに比較して角筫化を起し易いこるは 容易に推定されることである。また $10 \%$ 苛性ンーダ 楁液処理をしたすのの方が残留水分堂の高い段階から 角質化を起し始めることる同样な理由によるるのです る。な和同じ10\%狮性ソーダ処理を受けたるので 乾燥温度によって多少角質化を起す㩒子が異なるがて の理由についてははっきりしたことはわからない。次 飞脱水乾燥の種々の方法による角質化度の相違を実湘 した。水湿满維素試料から水を除去する場合，要ず水之 任意に混合し得るよ5な有機液体で置換し，あるいは 更に非極性の液体で䇴換して，鼠後にてれ等夜体を蒸 発して乾燥する方法は多くの研究者によって研究され， 工業的比実施されたものるるるがこ机等の場合の角 貲化度を追試した。結果は第 1 表の如くで，明らか心 䩇换して最後にそれを蒸発除去することによって乾燥

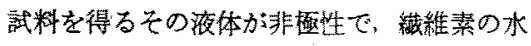
酸基に刘して親和性が小さく，また表面張力 の小さい場会程角筫化は起りにくいことがわ かる。すなおち, 表面張力が大きく,水酸基に 対する親和性の大きな極性液体程それが蒸発 て除去される時，維維絮の水酸基同志はより 強い力で相互に引き寄上られ，酦後にその液 体分子が完全に緎維素を離脱する時に水酸基 同志が相互作用の圈内に近ずいて種々の強さ の結合を起し，全体の組織が角買化を起す程 度がより顕著になるるのと説明される。なお このよらな有機液体で置换執噪する場合にも 起る角質化㥜換の段階で起るのではなく最 
第 1 表 有機液体置換乾燥に上る角質化の低減 原試料： $10 \% \mathrm{NaOH}$ 常温処理瀻稚素 $q_{0}=128.5 \%$

\begin{tabular}{|c|c|c|c|}
\hline 置 換 乾 & 条 件 & $\begin{array}{l}\text { 氷酰酸膨 } \\
\text { 閏吸収量 } \\
q(\%) \\
q(\%)\end{array}$ & $\begin{array}{c}\text { 角啠化度 } \\
r(\%)\end{array}$ \\
\hline \multicolumn{2}{|c|}{ 風 乾一（常 温） } & 41.0 & 68.1 \\
\hline \multicolumn{2}{|c|}{ 風 乾 $-105^{\circ} \mathrm{C}, 3 \mathrm{hr}$ 熱乾 } & 26.9 & 79.1 \\
\hline \multicolumn{2}{|c|}{ 风夕ノ一 ル置換 $-60^{\circ} \mathrm{C}, 10 \mathrm{~min}$ 乾燥 } & 62.8 & 51.1 \\
\hline \multicolumn{2}{|c|}{ フ七トン盖換 $-60^{\circ} \mathrm{C}, 10 \mathrm{~min}$ 乾燥 } & 70.8 & 44.9 \\
\hline \multicolumn{2}{|c|}{$\begin{array}{r}\text { メタノール置換-ェーテル置換一 } \\
60^{\circ} \mathrm{C}, 10 \mathrm{~min} \text { 乾燥 }\end{array}$} & 75.2 & 41.5 \\
\hline \multirow{2}{*}{\multicolumn{2}{|c|}{$\begin{array}{r}\text { ×タノール置換 }-60^{\circ} \mathrm{C}, 35 \mathrm{~min} \text { 乾懆 } \\
\text { ×タノール置換-ペンビン置換一 } \\
60^{\circ} \mathrm{C}, 10 \mathrm{~min} \text { 乾燥 }\end{array}$}} & 76.8 & 40.2 \\
\hline & & 83.2 & 35.3 \\
\hline \multirow{3}{*}{\multicolumn{2}{|c|}{ 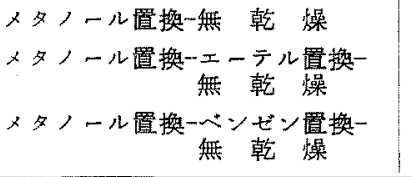 }} & 129.0 & - \\
\hline & & 107.0 & 16.7 \\
\hline & & 124.0 & 3.5 \\
\hline \multicolumn{4}{|c|}{ 参考資 } \\
\hline \multicolumn{2}{|c|}{ 有 機液 体 表面張力 $\left(20^{\circ} \mathrm{C}\right)$} & \multicolumn{2}{|c|}{$\begin{array}{l}\text { 水酸基之の } \\
\text { 親和性覑位 }\end{array}$} \\
\hline \multicolumn{3}{|c|}{$x>-ル 2$} & Shente \\
\hline $7 t+y$ & 23.7 & \multicolumn{2}{|r|}{2} \\
\hline \multicolumn{2}{|l|}{$x$ タ,$-ル$} & \multicolumn{2}{|r|}{ 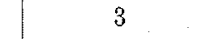 } \\
\hline \multicolumn{2}{|l|}{ × $-テ ル$} & \\
\hline ベンザ & 28.9 & \multicolumn{2}{|r|}{5} \\
\hline
\end{tabular}

媵の蒸発乾燥の段階でその大部分が起っていることも 実験の結果明らかになった。

\section{（3）眝蔵中の角質化}

次に一旦できるたけ角質化を起さないような方法で 乾燥した㵶維素試料を各種関係湿度の容器中に眝藏し その変化を観察した。結果は第 2 表に示す如くで，関 係湿度が高い程, 眝蔵時間が長い㻇, 酶酸膨润吸収量 $q$ は小さくなり, 明らが貯藏中汇角質化が起っだこ とを示している。すなわちここに用いた乹燥試料は 角質化度低く，换言すれば遊離の水酸基を豊富にるち， エネルギー的㐳不安定な状態次詰されているものと 考学られる。徒って適度の水分が与兄られればその涷 結は緩和されてエネルギー的に上り安定な角質化状熊 に向って変化してゆくものと考光られる。勿論ある程 度以上に関係湿度が高くなれば緩和は進み過ぎて元の 乾燥試料の角質化をる破壊するに至る。以上の実験結 果から有機液体で置換乾燥して製造した角質化度低く 反応性の高い緎維素原料は殆えど絶乾に近い状態で睦 蔵しないと䝪蔵中かなりの角質化を起して反応性を低
第 2 表 各種関係湿度中に貯藏した場合に起 万角買化

原試料: $10 \%-\mathrm{NaOH}$ 処理一水洗一メタノ一儿置換一ンゼン置換 $-60^{\circ} \mathrm{C}, 20 \mathrm{~min}$ 乾燥, $q=86.0 \%$, $r=33.1 \%$

\begin{tabular}{|c|c|c|c|c|c|}
\hline 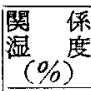 & $\begin{array}{c}\text { 貯 藏 } \\
\text { 時間 } \\
\text { hr } \\
\text { hr }\end{array}$ & $\begin{array}{c}\text { 眝蔵後の } \\
\text { 量 } \\
(\%) \\
(\%)\end{array}$ & 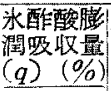 & $\begin{array}{l}\text { 角貨化度 } \\
(r)(\%)\end{array}$ & 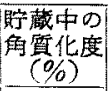 \\
\hline 0 & 120 & 0 & 86.0 & 33.1 & 0 \\
\hline 15 & 40 & 4.60 & 85.4 & 33.5 & 0.4 \\
\hline 25 & 40 & 5.52 & 83.2 & 35.3 & 2.2 \\
\hline 40 & 40 & 6.96 & 80.9 & 37.1 & 4.0 \\
\hline 40 & 120 & 8.64 & 78.4 & 39.0 & 5.9 \\
\hline 65 & 40 & 9.27 & 77.0 & 40.0 & 6.9 \\
\hline 65 & 120 & 11.7 & 68.2 & 46.9 & 13.8 \\
\hline 80 & 120 & 14.4 & 56.2 & 56.3 & 23.2 \\
\hline 100 & 100 & 51.0 & 121.0 & 5.84 & -27.3 \\
\hline
\end{tabular}

下するすのであることは注意しなければならぬ。

\section{（4）角質化繹維素の活性化}

濃厚アルカリ処理のような強膨潤処理を経た縄維素 は上述の如〉脱水乾燥に際し強〉角質化し, 各種の反 応に対する活性を著しく失うことはよく知られたこと である。なかんずく唒酸化反沁に打いては酰酸化混酸

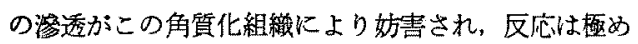

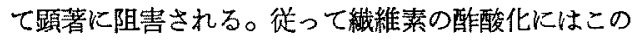
角質化組織の破壊, すなわち活性化方㳅可欠の前処理 工程となっている。本実験には $10 \%$ 苛性ソーダ溶液 で常温処理した後一定条件 (1 日風乾 $-105^{\circ} \mathrm{C} .3 \mathrm{hr}$ 加 熱)で乾燥してかなり強く角質化を起しな縄維素を試 料として各種前処理剤, 処理条件に上る活性化の程度 を処理後の試料の角質化度を測定することにより比較 しその活性化の機構を考察し, 併せて工業的前処理法 としての適否を検討した。活性化度（a）は

$$
a=\frac{r_{0}-r}{r_{0}} \times 100 \%
$$

で表わす，但し活性化处理前の試料の角質化度を $r_{0}$ と 乙, 処理後の角質化度を $r$ とする。酶酸化前処理剤と しての各種液体の性能は従来る研究されたが定量的に 検討したるのは比較的少ない。7種の液体について行 った穾験絬果を第3 表に示す。処理時間は何九む $1 \mathrm{hr}$ である。今試み江各液体の㠜集エネルギー密度 $\left(20^{\circ} \mathrm{C}\right)$ と $20^{\circ} \mathrm{C}$ て前処理後の氷酶酸膨潤吸収量 $q$ を比較する 之, 水酶酸を除けば, $q$, 従って活性化度 $a$ は凝集工 ネルギー密度の大なる液体で処理したすの程大きい值 
第 3 表 各種前処理削の活性化能力 原試料: $10 \% \mathrm{NaOH}$ 処理, 風乾, $105^{\circ} \mathrm{C}, 3 \mathrm{hr}$ 熱乾 $q=26.9 \%$

処理時間： $1 \mathrm{hr}$

\begin{tabular}{|c|c|c|c|c|c|}
\hline \multirow{2}{*}{ 前 処 理 妏 } & \multicolumn{4}{|c|}{$\begin{array}{l}\text { 処理後の耂酰酸澎潤吸 } \\
\text { 取量， } q(\%) \\
\end{array}$} & \multirow{2}{*}{ 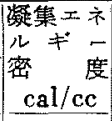 } \\
\hline & $\begin{array}{l}\text { 垔温度 } \\
20^{\circ} \mathrm{C}\end{array}$ & $40^{\circ} \mathrm{C}$ & $60^{\circ} \mathrm{C}$ & 蕉沸 & \\
\hline 水 & 68.5 & 64.3 & 66.4 & 66.8 & 551.1 \\
\hline ×夕夕一ル & 54.7 & 48.8 & 52.7 & - & 210.3 \\
\hline Iタ, 一 & 37.9 & 38.4 & 41.8 & 41.5 & 163.4 \\
\hline r t $r y$ & 35.2 & 35.5 & - & - & 98.5 \\
\hline 匹䆝化岩㟤 & 30.9 & 33.3 & - & - & 85.5 \\
\hline 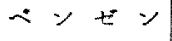 & 28.6 & 29.1 & - & 32.5 & 79.4 \\
\hline 米 䣲 & 28.0 & 39.5 & 48.2 & 45.2 & 91.4 \\
\hline$エ-テ ル$ & 26.8 & - & 一 & - & 54.1 \\
\hline
\end{tabular}

安示している。このことは角質化緎維素の膨潤活性化 を無定形紋維素の溶解現象と考学れば合理的に解釈さ れる。すなわち角質化した然定形絩維素の㠜集さネル ギー密度は知ることができないか恐らくメタノールと 水の中間位にあるのではないかと推定される。従って， ここに用いた簿囲の液体では凝集エネルギ一密度の大 きいるの程, 角質化䋡維素を溶解する力, 換言すれば 争質化組織を破罗する活性化能力が大きいと苦总られ る。な和処理温度の影暗を見るに水, メタノールの場 合 $40^{\circ} \mathrm{C}$ 処理のるは $20^{\circ} \mathrm{C}$ 処理に比較して多少活性 化度が低下するが $60^{\circ} \mathrm{C}$ ，募沸と再び增大してくる。 これは前処理剂による溶媒和膨潤反応の全熱量变化か:

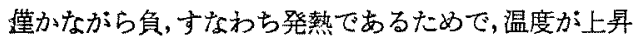
するにつれて再び増大寸るのは，低温では強く会合し ているこれ等処理蝺分子が会合をとかれ活性化能力の 大きい単分子状態の濃度圭增加するためと考克られる。 エタノール，アセトン，ベンゼンは温度の上年に伴な 心，何れ多次第に活性化能力を增与が，これ等は全熱 量変化が正，すなわち吸熱であるためと考えられ，特 にエタノールの場合は水，メタノールと同じように会 、合が解かれるための影響がこれに附加されるため温度 上年によりやや著しく活性化能力を增大するあのと考 えられる。更に头酿酸の場会は凝集エネルギー密度と の関係においてる例外であったが，温度の影琶るまた 例外的に大きく，処理温度 $20^{\circ} \mathrm{C}$ ではベンゼンと同等 の活性化能力をるっに過ぎないか， $60^{\circ} \mathrm{C}$ ではょタ， 一ルのそれに㪣する活性化能力を有する。承酿酸は 雕知の如く極めて強く会合し低温ては殆んど全部が 2
分子会合の状態をとっているが温度上年に伴ないこの 会合は解かれ単分子状態で存在するるのの濃度が增大 し，活性化能力を增すが，この会合熱が大きいため単 分子状態ののの濃度の温度による增え方が比較的大 きいすのと考えられる。帚際工業的の前処理剤として， しばしば氷酷酸が用いられるが，上記の実娩結果より すれば少くとす $60^{\circ} \mathrm{C}$ 程度に温度を上年させねね゙有効 な前処理効果は期待できない。な叔徒来前処理用酷酸 に硫酸あるいは酶酸ソーダを添加することが有效であ るとされているが，これについて実驗した結果を第 4 表に揭げる。結果は何れを港加してる活性化能力は殆

第 4 表 水酢酸の前処理效果に対する添加乵の 影響

前処理条件： $20^{\circ} \mathrm{C}, 1 \mathrm{hr}$

\begin{tabular}{|c|c|c|c|c|c|c|}
\hline $\begin{array}{l}\text { 添加剂々 } \\
\text { その㴚度 }\end{array}$ & 無添加 & $\begin{array}{cc}1 & \% \\
\text { 硫 酸 }\end{array}$ & $\begin{array}{l}5 \\
\text { 硫 }\end{array}$ & $10 \%$ & 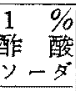 & 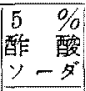 \\
\hline $\begin{array}{c}\text { 処理淩の } \\
q(\%)\end{array}$ & 28.0 & 27.3 & 28.1 & 27.2 & 28.2 & 26.3 \\
\hline
\end{tabular}

えど変化なく，むしろ多少减少する傾向さえ見られる。 すなわち，硫酸等は眽酸化反応そのわのの触媒として は極めて有効でするが，角質化組禨の破壊による酷酸 化前処理には全く効果が認められない。但し触煤とし ての硫酸を妁一に繧維素原料に浸潤させて置く意味の

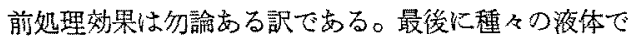
前処理する際の機械的摩砕の与竞る效果を検討した。 結果は第5表に示す。何孔摩碎の効果の大きいこと,

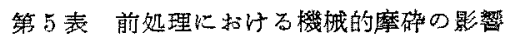
$20^{\circ} \mathrm{C}, 1 \mathrm{hr}$

\begin{tabular}{|c|c|c|c|c|c|c|c|}
\hline 前 処 理 斉 & 水 & $\left.x^{3}\right)$ & Is) & $\left|\begin{array}{ll}7 & t \\
1 & \ddots\end{array}\right|$ & $\mid \begin{array}{l}\text { ヒீン } \\
\text { ヒீ人 }\end{array}$ & 酷酸 & 乾燥 \\
\hline $\begin{array}{l}\text { 摩研しない場 } \\
\text { 合の } q(\%)\end{array}$ & 68.5 & 54.7 & 37.9 & 35.2 & 28.6 & 28.0 & \\
\hline $\begin{array}{l}\text { 縻硶した場合 } \\
\text { の } q(\%)\end{array}$ & 138.2 & 104.2 & 66.4 & 73.5 & 47.2 & 60.5 & \begin{tabular}{l|l}
5 & 34.
\end{tabular} \\
\hline
\end{tabular}

すなわち糜硫により水酸基同志の結合が機械的に破壊 されることを示し，膨潤力の強い液体中では特に有効 であることが分る。

\section{総括}

綪維素の角質化及び角質化瀻維素の活性化を試料の 氷酷酸膨润吸収量を測定することにより检討した。得 られた結果は次の如くである。

（1）脱水乾燥過程において大然維維絭ては残留水分 
量的 $50 \%, 10 \%$ 苛性ソーダ処理緎維害では䄪 $80 \%$ 以 後角質化が顕著比起る。

（2）有機液体置換一乾燥により角買化は相当汇防止 されるが，その際，表面張力小さく，水酸基との親和 力小さい非極性液体程角質化防止に有効でる。

(3) 角質化を起させないように乾燥した絾維索を適 度の関係湿度の容器中に聍蔵すると詝蔵中顕著な角質 化を起す。

（4）角質化絨維絜の活性化には凝集エネルギー密度
の大きな液体程有糼である。求醀酸はやた高温で活性 化能力を発揮する。

(5) 機械的処理の併用は活性化比極めて有效てある。 付記 本研究を行5に当り研究費の一部を文部省科 学研究費に負った。記して謝意を表する。

ま大本研究の前半は綪維学会昭和 28 年秋期研究笔 表会で, 後半注日本化学会第 7 年会 (昭和 29 年 4 月) でそれぞれ発表した。

\section{海外だより}

目下アメリカの Institute of Paper Chemistry, Appleton, Wisconsin に留学中の本学会評議員, 編集委 員松崎整氏 (東大応用化学科教室)より下記のよ5な便りをいただきましたのでここに揭載いたします。

9 月 25 日ニューヨークよりシカゴに飛び，シカゴからバスで6時間半を要し，アプルトンに着く。翌日 より The Institute of Paper Chemistry に毎日通う。ここは Tappi に報告を出して世界的に知られてい る学者が多く、へミセルロースの L. E. Wise, リグニンの Dr. Pearl, Dr. Brauns, Dr. Buchanan 等が括 られる。Dr. Brauns は最近喈しくも退職されてカナダに移られた。

もう大分前になるが10月6日 Madison の Forest Products Laboratory を私の指導教授 Dr. Kyle Ward と共代訪問した。そこでアメリカ化学会（9月11日〜16日ミネアポリスに開かれた）に出席し，さら に西部を京わってちょうど Madison に帰ってきたドイッのダルムシュタットエ科大学教授 Dr. Jayme 夫 妻比招目にかかる機会を得た。Jayme 夫人は以前われわれの研究所の图書係をして招られたことを聞いた のも興味深い。

Forest Products Lab. では Tappi 37. 336 (1954) に発表されているペーパークロマトグラフィーの装 置, その操作法などをたずね、さらに Dr. Jayme の講演を聞いた。講演の内容は既に Das Papier に発表 されているよ5であるが大要次の通りである。一材の横断面を電子顕微鏡で調べてる第一次層はりグニ ンの層中に埋まつていて直接見ることはできない。クラフトパルプの電子影徽鏡的研究は予想に反して第一 次署は去の破片が見られるだけで，蒸解により第一次層の大部分が失われ第二次層か婊面に露出しているこ とを示した。サルフフイトパルプでは逆に第一次層が殆んど完全に残っている。又ピットのまわりに特にり グニンが残存していることが見られた。クラフトパルプを水処理した後乾燥すると、フイブリルが物理的に 凝集してくることが認められ，こ机が角質化の原因と考允られる。一-Madison上り帰り，Jayme 夫妻と レストランに立寄り御馳走にあずかったが，その時のメンパーは全く International で Dr. Ward (米), Dr. Jayme (独), Mrs. Jayme (Dr. Jayme によ杖ズスーデン人), Dr. Pridham (J.K.N. Jones の弟子, Bristol 大学出身 英), Miss Lakstigala (ラトビア) と私でお互にレストランの絵葉書にサインして記念 にした。

11 月 15 日2回にわたり Dr. Richter の「んセルロースのパルプの調整と性質」と題する講演を聞いた。 Dr. Richter はもと Broun Co. にいた人で 1941 年 Eastman Kodak Co. に移り主として高アルファパル プの研究を続けて扔られる。彼の報文は1940年の始めの Ind. Eng. Chem. にたくさんあったと記憶してい る。請演は Tappi, 38, 129 (March 1955) と殆えど同じであるが大要を次に記す。一所謂れセルロース のアルカリ抵㧧性を説明する因子として分子量，カルボキシル基などの有無のほが架橋結合が考六られる。 架橋には瀻維素がペントザンと化学的に結合しているような形の架橋が考古られる。高 パルルプ製造法と して亜硫酸ペルプの 1. 稀アルカリ高温処理 2 . 高濃度アルカリ低温処理と稀アルカリ高温処理の組合せ, ク ラフトパルプよりの 3. 高濃度アルカリ低温処理, 4. 前加水分解法の 4 つの方法が工業的に行われていて, Spruce に注第 2 法, Hemlock には第1 法が行わ机ている。第3 法にはナッチェスが属する。クラフト法 は現在のところ酢化用パルプには不適当である。第 4 法のプリハイドロシス法で水の代りに要硫酸塩を使っ てやると鉒の腐蝕が起らず，漂白も容易で，色戻りる少い。前加水分解仗用いる薬液は 4 回は繰返して使え る。 